\title{
Ukraine in a Geopolitical Game between the West and the Russian Federation
}

\author{
Wiktor Możgin \\ Ph.D. Student, Jagiellonian University in Kraków (Kraków, Poland) \\ E-mail: viktor1990@wp.pl \\ https://orcid.org/0000-0001-5744-8103
}

\begin{abstract}
The beginning of the $21^{\text {st }}$ century told all observers of international politics about the phenomenon of a rivalry revival between the West and the Russian Federation. Moscow's resurgent imperialist aspirations are being negated both by the United States and by the countries of the European Union. In the context of world events, Washington loses its hegemonic position in favor of the reviving powers, which Russia is also included to nowadays. The territory of the Ukrainian state is the area in which the active phase of rivalry between the West and the Russian Federation currently takes place. The Donbas war is an exemplification of the Kremlin's expansionist plans, because by destabilizing the integrity of Ukraine, Russia wants to restore control over this territory. This raises the fundamental issue concerning the subjectivity of Ukraine in the international arena. Therefore, will Ukraine be able to cope with the struggle of the great powers in the context of geopolitical clash, in which it is treated as the object of struggle? The multifaceted nature of this phenomenon is the basis of this article, which presents the situation of Ukraine in the context of the geopolitical rivalry between the West and the Russian Federation.
\end{abstract}

Keywords: geopolitics; objectivity of the state; Ukrainian-Russian war; destabilization; Ukraine

Received: October 23, 2018; accepted: November 19, 2018

Ukrainian Policymaker, Volume 3, 2018: 36-42.

https://doi.org/10.29202/up/3/5

\section{Introduction}

The end of the twentieth century was a time of significant changes on the international scene in the context of relations between individual countries. The decisive factors in this period were two specific phenomena - the collapse of the Soviet Union and the departure of the bipolar system of international relations for the US hegemony. At that time, Washington's priority was to negotiate such conditions that the heiress of the Soviet Union - the Russian Federation - would not be a threat to American interests around the world [Stent, 2005: 259261]. Bill Clinton, in his policy towards Russia, was guided by the conviction that the rulers of the Kremlin did not satisfy their post-imperial ambitions. Consequently, it was not possible to rule out the factor destabilizing the post-Soviet space that Russia would use to rebuild its

(C) Możgin, Wiktor, 2018 
superpower position on the international arena. That is why one of the main assumptions of the US foreign policy in this period in relation to the Eastern European states arising from the collapse of the USSR was to support the building of independent and democratic state structures and to stop Russia's expansionist activities in the region [Stent, 2005: 263-265].

The beginning of the 1990s was a period of political weakness of the Russian Federation in the international arena. The reins of power were in the hands of people open to relations with the West. The president of the country, Boris Yeltsin, the prime minister and minister of finance, Yegor Gaidar and the minister of foreign affairs Andrei Kozyriev, based their policies on the "Kozyriev doctrine" then in force (from the name of the above-mentioned Minister of Foreign Affairs, Kozyriev). It was an exemplification of Russia's submission to the West. The fundamental message of this document was the postulate of reconciliation with the hegemonic position of the United States in building the post-Cold War order and the adoption of principles and values prevailing in the West.

This submission was only an illusion created by the authorities in the Kremlin in relation to their Western partners. Russia has never abandoned the ambition of being a superpower in the international arena. From the point of view of Moscow's expansionist rhetoric the restoration of control over the area of the then "Soviet" empire was very important. The foreign policy of the Russian Federation changed radically with the arrival of Vladimir Putin, because the place of communist ideology was occupied by geopolitics encapsulated by specific Russian imperialism [Święchowicz, 2014: 38-40]. The shape of the policy pursued by the Kremlin against other states was well defined by British international relations researcher Janusz Bugajski who said that Russia had returned to the international arena as a significant player with its own projection of superpower identity. The imperative of policy towards the United States is to undermine their superpower status and to establish close cooperation with nontertiary countries, as well as skilful use of energy resources to increase their influence in the area of the former Soviet Union [Bugajski, 2004: 20-23].

The destabilization of Ukraine lasting with fluctuating intensity since the appearance of this state on the political map of the world is the strategic plan of the Russian Federation included in virtually every foreign policy document. The 2014 became a precedent in contemporary Ukrainian-Russian relations. Russia's actions towards Ukraine have brought to an end many illusions that Russia is a fragile construct whose potential is based on the achievements of the then Soviet empire. Moscow has been firmly committed to the process of rebuilding the superpower position in the international arena.

The conflict in Eastern Ukraine is an important determinant influencing the redefinition of the relationship between the West - the United States and the European Union - and the Russian Federation [Olchowski, 2017: 154]. Ukraine in this context appears both as an entity and as an object in the superpower game for influence on the international arena. The articulation of the above statements is the basis for a deeper geopolitical analysis of the situation in Eastern Europe in the context of the Ukrainian-Russian war that has been ongoing since 2014.

\section{Subjectivity and Objectivity of Ukraine at the International Arena}

The Russian Federation was skeptical about the act of state independence proclaimed in 1991 by the Ukrainian Verkhovna Rada [Olchawa, 2009, 14-15]. The American international relations researcher from the University of Pittsburgh Ilya Prizel pointed out that the emergence 
of an independent Ukraine on the political map of the world was a blow to national Russian self-perception [Prizel, 1994: 117-118]. The multi-vector policy pursued by Ukraine towards its strategic partners did not give rise to radical actions on the part of the Russian Federation. The presidency of Viktor Yanukovich was a favorable time for the Kremlin authorities to build a strong network of connections with the Ukrainian state. Practically every sphere of the functioning of the state was more or less subordinated to the Russian influences. In 2013, when the Ukrainian people expressed their aversion towards the pro-Russian political elites realizing their particular interests led to the bankruptcy of the Ukrainian statehood, and decided to strongly associate with the Western structures, it was a clear sign for the Russian authorities that Ukraine was slipping out of control, which was unacceptable in the context of the reconstruction of Russia's imperial position.

Ukraine, in accordance with the geopolitical strategies of both the United States and the Russian Federation, is a buffer state - the territory that is a contentious issue in the rivalry between Washington and Moscow. A few decades ago an outstanding American researcher of international relations Zbigniew Brzezinski in his work The Grand Chessboard: American Primacy and Its Geostrategic Imperatives stressed that the importance of Ukraine does not result from the country's power, but from an important geographical location [Brzezinski, 1998: 49-51]. In this aspect, the Ukrainian state is treated by the rival parties as an object within the international arena.

The reasons for this state of affairs should be found in both external and internal factors. The former include, among others, the weakness of Ukrainian diplomacy in the international arena and nuclear disarmament, which became the basis for the signing the Budapest memorandum.

The West in August 1991, establishing relations with Ukraine as a newly-established entity on the political map of the world, did not rush with the official recognition of the independence of this state, as it happened in relations with the former Baltic republics that were part of the USSR. The explanation of this may be that on one hand Western states did not want to spoil relations with the still existing Soviet Union, and on the other - these countries never recognized legally that Lithuania, Latvia and Estonia are part of the USSR [Chekelenko, 2006: 51-54]. On the other hand, Ukraine was an unknown state for the West, in the sense that all spheres of its functioning were connected with the "center" located in Moscow. Obviously, the Baltic States were also an inseparable part of the Soviet Union, but their geographical location, or rather its importance, was previously noticed by Western countries rather than Ukraine. Kiev was a specific case in the matter of building diplomatic relations with other countries. The multi-vector policy and the lack of decisiveness in making specific decisions constituted an obstacle for creating a strong diplomatic background.

The weakening position of the Ukrainian state in the international arena was also caused by the fact of nuclear disarmament. In 1992, Ukraine was the third largest power in terms of the size of its nuclear arsenal, being in this juxtaposition just behind Russia and the United States. Both in Washington and in Moscow, this was clearly a matter of concern. The fears of the nuclear powers were reduced to the fact that in early 1992 Ukraine gave up the possession of nuclear weapons by transferring all missiles to Russian arms factories, where they were destroyed [Yekelchyk, 2007: 201-204]. The next step was signing in Lisbon through Ukraine, Belarus and Kazakhstan an annex to the US-Soviet agreement on the reduction and reduction of strategic armaments (START I). Confirmation of the final stage of getting rid of the nuclear arsenal by Ukraine was the signing of the Budapest memorandum in 1994 [Kuzio, 1995: 103-106]. An important assumption of this document from the point of Ukraine's view was 
to guarantee security in connection with the accession of the Ukrainian state to the Treaty on the Non-Proliferation of Nuclear Weapons. The signatories of this agreement (the United States of America, the Russian Federation and the United Kingdom) undertook to respect the sovereignty and integrity of the Ukrainian state. The contents of the Budapest memorandum also resulted in the guarantee of security for Ukraine from Washington, London and Moscow. Under this document, the signatory states promised to refrain from territorial disintegration and violation of the political and economic independence of the Ukrainian state [Yekelchyk, 2007: 211-212].

As far as building subjectivity on the international arena is concerned, since the independence in 1991 Ukraine committed a number of errors that resulted in its objectification by stronger players, especially the Russian Federation.

The subject character of Ukraine in the international arena is the result not only from external factors but also internal - lack of political consolidation, corruption, oligarchisation of the political sphere and economic dependence on the Russian Federation.

Lack of political consolidation is manifested by the slow introduction of political and economic reforms. It would seem that the revolution of dignity would be an impulse for the emergence of a new political force that will lead the Ukrainian state to the path of development. Despite complex political promises, the country that is struggling with the war on a part of its territory is still in political stagnation. The goal for most political parties is to pursue their particular interests, which are not necessarily always consistent with the interests of society. In 2017, following the Corruption Perceptions Index (Transparency International) Ukraine was on 130 place with 180 countries under consideration [Transparency International, 2017]. In comparison to 2016, the Ukrainian state made progress, because then it was at 131 position [Transparency International, 2016]. This is an effect caused by the adoption of laws to combat political and economic corruption. Anti-corruption activities are still at a very low level because Ukraine is invariably at the end of the ranking among the largest corruption-free countries in the world.

Contemporary Ukrainian politics is based on the links of oligarchs controlling the major part of the state's economic sector with the representatives of the authorities. There are no real party borders, real debates and ideological battles in the Verkhovna Rada. There is only the interest of the elites who after the revolution of dignity again subordinated their legislative control to Ukraine. In Ukrainian politics, what counts is the division of interests and the distribution of influence, allowing controlling the business and financial sphere of the state, when the social interest remains in the background.

The economic dependence, which has also been mentioned as a factor weakening Ukraine's position on the international arena, is the result of a long-term functioning in the country of the planned economy. The presence of Ukraine among the countries of the Soviet Union, in which such economic solutions prevailed, contributed to the dispersed production centers throughout the territory of the USSR. Nevertheless, the entire economic infrastructure in Ukraine is in an outdated state comparing to the developed Western economies. Despite economic and development complications, Ukraine attracts more and more investors each year, which raise the Ukrainian economy to a higher world level.

The author's intention is not to analyze phenomena affecting the objective character of Ukraine in the international arena. In the context of this article, it is only important to signal the factors that cause this state of affairs. The contemporary geopolitical situation in which Ukraine appears as the object of the imperial game between the West and the Russian Federation is the 
result of mistakes made by the Ukrainian authorities both in the relationship of intra-state policy and foreign policy.

\section{Constellations of Russian Foreign Policy towards the West}

The Russian Federation skillfully uses the liberal-democratic system prevailing in the West. Political correctness prevailing especially in the European Union countries is treated instrumentally by the authorities in the Kremlin. A few years back, it would seem that Russia is starting to treat the West as an equal partner. The fight against international terrorism, the blocking of Iran's actions in the sphere of development of the nuclear program and cooperation in the reconstruction of state institutions in Afghanistan - these are just some of the aspects of Moscow's cooperation with Western partners. Despite such outlined constellations, Russia did not stop at implementing its expansionist plans. The exemplification of these activities is the active phase of destabilizing the integrity of the Ukrainian state, which has been ongoing since 2014.

In this context, it is important that the reaction of the European Union, not the United States, was the most severe for Russia in connection with the war in the east of Ukraine. Washington, for purely pragmatic reasons, limited his reaction only to political and economic sanctions. For the United States, it was not so much Russia's involvement in the Donbas war that mattered much, but Moscow's action in the context of the presidential election in the United States and the involvement of the Russian side in the war in Syria [Olchowski, 2017: 162-163].

The European Union, as a subject of international politics, reacted to the Ukrainian-Russian war in a more decisive manner. This is directly related to economic, social and security policy. However, sanctions against Russia imposed by the European Union have been of a minor nature, because it works in this area in such a way as not to violate the particular interests of individual states. It is worth remembering that the interests of the European Union as a subject are not always consistent with the interests of individual member states.

The Russian Federation is very active in this field using intra-EU divisions. To this end, it supports various extreme political and social groups - both right and left [Olchowski, 2017: 163]. Russian lobbying in the European Union is important in this context. One of the aspects of this lobbying is Moscow's plans to establish a representative office for Crimea in Brussels. It is aimed to recognize the annexation of the peninsula and to abolish sanctions against the occupation authorities. The implementation of this undertaking will depend on the support of EU politicians affiliated with Russia coming from the nationalist parties of Austria and Belgium, representatives of Latvia acting for the benefit of the Russian minority and Czech MEPs belonging to the Communist Party [Laru, 2018]. It was planned that the representative office will be opened in the first half of 2019 and will function as the official lobbying group on the territory of the European Union. Vlaams Belang, a representative of the nationalist party Flemish interest, is optimistic about the Kremlin's idea, claiming that the creation of a representative office will help to support foreign investments on the peninsula, which will undoubtedly contribute to the economic development of the region. A similar narrative is conducted by the representative of the communist Czech party Jaromír Kohlíček. Postulates that the issue of cooperation with the Crimean peninsula will contribute to the normalization of relations with the Russian Federation [Laru, 2018].

Another aspect is the information war carried out in relation to the European Union countries. A special case in this context is the question of Polish-Ukrainian relations. Poland 
is Ukraine's closest neighbor and constitutes an important foundation in relations between the Ukrainian state and the European Union. Russia uses historical events connected with the Polish-Ukrainian war at the beginning of the 20th century, and also - with the glorification of the Ukrainian Insurgent Army by the current Ukrainian authorities, whose ideology was truly anti-Polish. Moscow uses these facts to disrupt Polish-Ukrainian relations, thereby undermining the authority of Ukraine in relations with the European Union.

The indicated aspects in the relations between the West and the Russian Federation are only an outline of the wider phenomenon of Russian lobbying in the European Union, as well as the manner of implementing Russian foreign policy towards the West.

\section{Conclusions}

Moscow today, despite criticism of the international environment, is implementing one's expansionist plan towards Ukraine. Vladimir Putin chose a convenient moment for the attack on Ukraine, because the state had been in disarray after the Revolution of Dignity, during which the Ukrainians expressed their aversion towards then President Viktor Yanukovich. In 2014, there were no political forces in Ukraine capable of taking the situation into their own hands and managing the state so as not to allow a conflict in the eastern part of the country. The weakness of the Ukrainian political elites, which are mostly oligarchized clans, manifested itself in the lack of decisive actions against the Russian aggressor. No wonder that Russia, taking advantage of the convenient situation, under the guise of helping pro-Russian people of the Donbas, took part of the eastern regions of the Ukrainian state.

Moscow has now created an extensive system of fighting with the West. One of the elements of this system is the hybrid war, which is an effective tool in the hands of the Russian rulers. The geopolitical game between Moscow and Washington today is a phenomenon that is commented on around the world. However, the reaction of some entities, especially in Western Europe is quite surprising. The existence and resilience of the so-called the "fifth column of the Kremlin" is an element of the geopolitical game of the Russian leader towards the West. Diplomacy, propaganda and energy resources form the Kremlin's bargaining chip in relations with European countries. Those interested in the implementation of their particular interests, some German, Hungarian, Slovak, Austrian, or Greek politicians are economic and political partners of the Russian authorities.

The geopolitical rivalry between Washington and Moscow is nothing more than a rivalry for world domination. Ukraine, in this game, is only a resource for which fighting is currently being fought.

\section{[D] References}

Brzeziński, Zbigniew. Wielka szachownica. Główne cele polityki amerykańskiej, Warszawa, 1998.

Bugajski, Janusz. Cold Peace: Russia's New Imperialism, Westport, 2004.

Kuzio, Taras. Ukrainian Security Policy, Washington, 1995.

Olchawa, Maceij. Imperialna Rozgrywka. Ukraina w geopolitycznej strategii Stanów Zjednoczonych, Kraków, 2009.

Olchowski, Jakub. Wojna hybrydowa Rosji na wschodzie Ukrainy w kontekście współczesnych stosunków międzynarodowych. Wojna hybrydowa Rosji przeciwko Ukrainie w latach 2014-2016, red. W. Baluk, M. Doroszko, Lublin, 2017. 
Prizel, Ilja. Ethnicity and Foreign Policy in Ukraine. National Identity and Ethnicity in Russia and the New States of Eurasia, Armonk, 1994.

Stent, Angela E. America and Russia: Paradoxes of Partnership. Russia's Engagement with the West, ed. A. J. Motyl et al., Armonk, 2005.

Święchowicz, Tadeusz. Imperium zła. Reaktywacja, Łódź, 2014.

Yekelchyk, Serhy. Ukraine: Birth of Modern Nation, New York, 2007.

Chekalenko, Ludmyla. Foreign Policy of Ukraine, Kyiv, 2006.

Laru, Dmitrii. Window to Europe: The Crimean representative will appear in Bruxelles. 13.11.2018. https://iz.ru/809990/dmitrii-laru/okno-v-evrosoiuz-v-briussele-poiavitsiapredstavitelstvo-kryma

Transparency International, Corruption Perceptions Index 2016. https://www.transparency. org/news/feature/corruption_perceptions_index_2016

Transparency International, Corruption Perceptions Index 2017. https://www.transparency. org/news/feature/corruption_perceptions_index_2017 